\title{
Algal swamp, marginal and shallow evaporitic lacustrine lithofacies from the late Devonian - early Carboniferous Albert Formation, southeastern New Brunswick, Canada
}

\author{
D.C. Carter* and R.K. Pickerill:" \\ *Nova Scotia Department of Mines and Energy \\ Box 1087, 1690 Hollis St., Halifax, N.S. B3J $2 X 1$ \\ * Department of Geology, University of New Brunswick, \\ Fredericton, N.B. E3B $5 A 3$
}

\begin{abstract}
The Albert Formation in the Moncton Subbasin of southern New Brunswick was essentially deposited in a complex series of spatially and temporally inter-related alluvial fan, fluvial-deltaic and "deep" water lacustrine depositional environments and which have all previously been described in detail. Herein we describe three depositional environments and their lithofacies which have not previously been described in any great detail, but constitute an integral part of the succession. These are the algal swamp, marginal (shoreface and carbonate mudflat) and shallow evaporitic lacustrine environments and their lithofacies.

Algal swamp lithofacies are characterized by kerogenous mudstones and inorganically precipitated nodular and phylloid or stromatolitic algal carbonates. Marginal lacustrine lithofacies are represented by two distinctive assemblages, namely carbonate mudflat and shoreface lithofacies. The former are characterized by dolomitic shales and interbeds of argillaceous limestones, aphanitic dolostones, siltstones and rare kerogenous and sub-kerogenous mudstones. The latter are characterized by $0.5-1 \mathrm{~m}$ thick sandstones and interbedded shales or mudstones. Both exhibit evidence of ephemeral exposure. Evaporitic lacustrine lithofacies are characterized by halite, gypsum, glauberite, anhydrite and dolostone with associated shales and siltstones containing molds of evaporite minerals replaced by calcite.

Using surface and available drill data an assessment of the spatial distribution, both within the Moncton Subbasin itself and with respect to associated depositional environments, of these lithofacies is made.
\end{abstract}

La Formation d'Albert dans le sous-bassin de Moncton s'est accumulee essentiellement dans une série complexe d'environnements de dépôt, genres cône de déjection, fluviodeltaique et milieu lacustre à tranche d'eau "profonde". Ces derniers ont tous fait l'objet de descriptions antérieures détaillées et l'on peut les mettre en corrélation spatiale et temporelle. Dans cet article on décrit trois milieux de dépôt ainsi que leurs faciès lithologiques qui n'ont auparavant fait l'objet d'aucune description en détail mais qui font cependant partie intégrante de la succession. Ce sont les environnements de marecage algaire, de milieu lacustre marginal (shoreface et vasière à carbonates) et evaporitique peu profond.

Les types faciologiques du marécage algaire sont principalement des mudstones à kérogène, des carbonates algolaminés (stromatolithes) et des carbonates noduleux ou en plaquettes précipités de façon inorganique. On retrouve deux assemblages distincts de lithofaciès de bord de lac, ce sont, respectivement, la vasière à carbonates et le shoreface. Le premier se caractérise par des argilites dolomitiques interlitées avec des calcaires argileux, des dolomies cryptocristallines, des siltstones et de rares mudstones plus ou moins riches en kérogène. Le second assemblage comprend des bancs de grès de 0.5-1.0m d'épaisseur interlités avec des argilites ou des mudstones. Tous deux présentent des marques évidentes d'exposition subaérienne sporadique. Le lithofaciès lacustre à évaporites contient surtout de la halite, du gypse, de la glaubérite, de l'anhydrite et de la dolomite associés à des argilites et des siltstones qui renferment des moulages de minéraux évaporitiques remplacés par de la calcite.

L'utilisation des données de la geologie de surface ainsi que des forages disponibles, tant dans le sousbassin de Moncton même qu'en ce qui concerne les milieux de dépôt qui lui sont associés, permet une évaluation de la distribution de ces lithofaciès dans l'espace.

[Traduit par le journal]

\section{INTRODUCTION}

The Albert Formation is the medial of three formations which constitute the late Devonian-early Carboniferous Horton Group which lies within the Moncton Subbasin (Figs. 1,2) of southeastern New Brunswick. The Horton Group represents the basal division of a complex succession of postorogenic molasse sediments typical of those infilling the Maritimes Basin (Knight 1983), a series of northeasterly trending horsts (arch), graben (basin) and platform structures which extend over much of New Brunswick, Nova Scotia, the Gulf of St.

MARITIME SEDIMENTS AND ATLANTIC GEOLOGY $21,69-86$ (1985)
Lawrence and western Newfoundland (Fig. 1). The Maritimes Basin, also previously referred to as the Fundy Basin or Fundy Epieugeosyncline, was characterized by the deposition of non-marine fluviatile and lacustrine sedimentary rocks from Late Devonian to Early Permian time (Belt 1968, Hacquebard 1972, Poll 1972). The only marine incursion into the Maritimes Basin took place during the Middle Mississippian (Visean) when a cyclic sequence of marine carbonates, evaporites and siltstones was deposited (Schenk 1967, McCutcheon 1981). The remaining Late Devonian and Carboniferous sequences were deposited within 
alluvial fan (piedmont), fluvial-deltaic and lacustrine environments.

In southeastern New Brunswick, the molasse sequence of the Horton Group is subdivided into the basal Memramcook, medial Albert and upper Moncton formations as indicated in Figure 3 (Greiner 1962, Howie 1968, Pickerill and Carter 1980, Carter and Pickerill 1985). This succession of alluvial fan, fluvial-deltaic, lacustrine and associated lithofacies accumulated in the northeast trending, southwest narrowing Moncton Subbasin, part of the much larger Maritimes Basin of Knight (1983). The Moncton Subbasin is bounded on the northwest by the Kingston-Indian Mountain Uplift and on the southeast by the Caledonia Uplift. To the east it is bounded and bifurcated by the Westmorland Uplift. The Caledonia Uplift was an active source area during deposition of the Horton Group providing coarse-grained clastic material which was deposited as alluvial fanglomerates and associated lithofacies, marginal to the up-

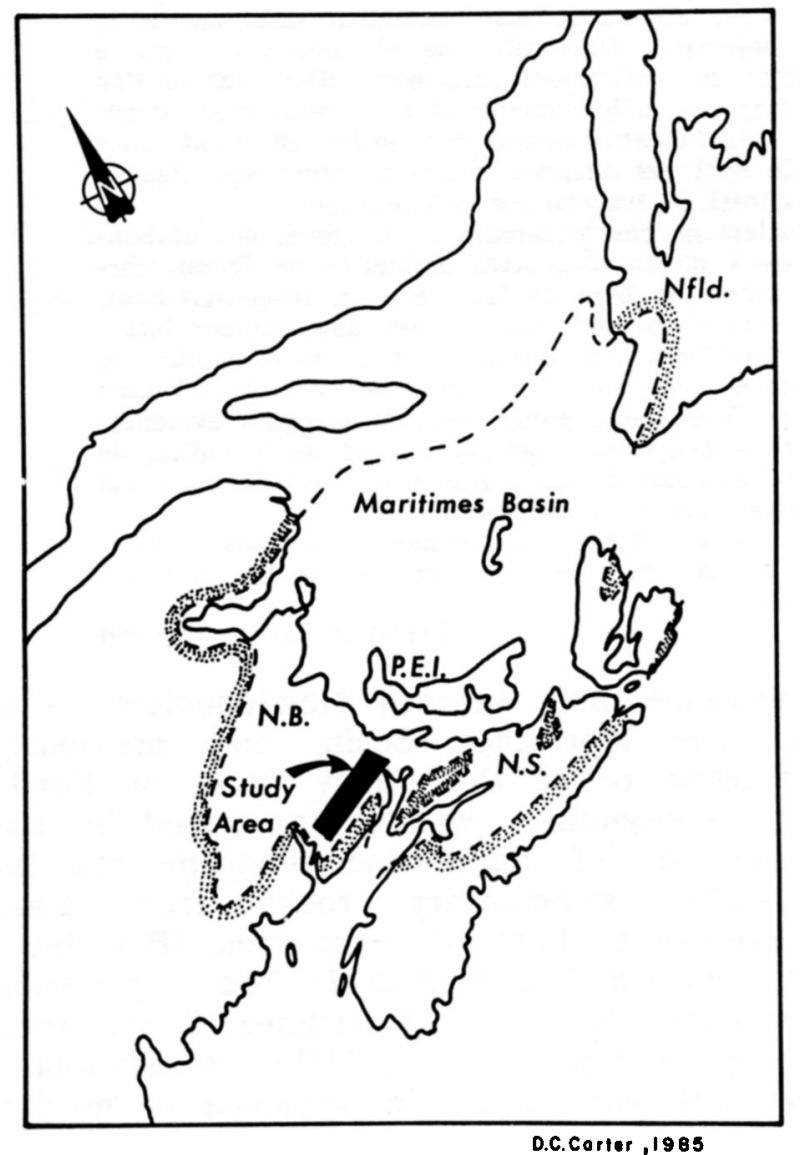

Fig. 1 - Distribution of the Maritimes Basin of eastern Canada and geographic location of the Moncton Subbasin, southeastern New Brunswick. lift (Pickerill and Carter 1980, Pickerill et al. 1985). The Kingston-Indian Mountain and Westmorland uplifts were both post-depositional passive margins (Pickerill et al. 1985)

The Albert Formation has in the past attracted many detailed sedimentological studies but, and for obvious reasons, particular attention has been given to the lacustrine oil shales which constitute an integral portion of the formation particularly in the Stoney Creek and Dover oilfields south of Moncton (e.g. Norman 1932, Henderson 1940, Greiner 1962, Howie 1968, Macauley and Ball 1982, Macauley et al. 1984). Such oil shales (actually kerogenous dolomitic marlstones) have been interpreted to have been deposited in relatively "deep" lacustrine environments in extremely quiescent conditions below wave base under reducing conditions (King 1963, Pickerill and Carter 1980, Smith 1985, Pickerill et al. 1985). The actual water depth involved is difficult to realistically assess but Pickerill and Carter (1980) suggested it was no more than several tens of meters. Associated fluvialdeltaic and alluvial fan lithofacies, which also constitute an integral proportion of the formation and occur in both the southeast, particularly, and southwest parts of the subbasin, have been described in considerable detail elsewhere (e.g. Greiner 1962; Howie 1968, 1979; Pickerill and Carter 1980) Only general sedimentological analyses of the entire Moncton Subbasin have, to date, been presented (e.g. Greiner 1974, Pickerill and Carter 1980, St. Peter 1982, Pickerill et al. 1985) and certainly no detailed descriptions of algal swamp, marginal and shallow evaporitic lacustrine lithofacies have until now been presented. The purpose of this paper is therefore to describe these lithofacies and to emphasize their spatial development within the subbasin.

\section{GENERAL BACKGROUND}

The Horton Group, and in particular the Albert Formation, is beset with numerous stratigraphic complexities as a result of the spatial and temporal development of its varied lithofacies. Figure 3 summarizes these stratigraphic relationships and a more detailed discussion of the formational and member contacts is given in Carter and Pickerill (1985). Figure 4 illustrates in a general way the spatial development of the 


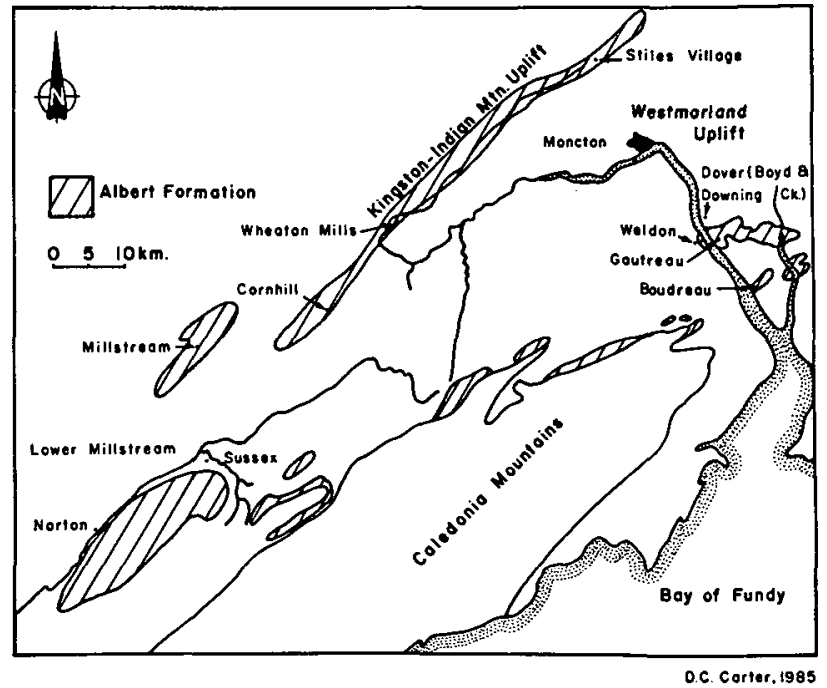

Fig. 2 - Surface outcrop of the Albert Formation in the Moncton Subbasin and location of bounding uplifts and localities referred to in the text (modified after Macauley and Ball 1982).

different members of the Albert Formation in different areas of the Moncton Subbasin. As a result of this spatial variation, different portions of the subbasin are subject to different stratigraphic nomenclature, though this particular aspect is beyond the scope of this paper.

Available surface and subsurface (drill) data combined with geophysical (gravity and aeromagnetic) information have been utilized by Carter and Pickerill (1985) to construct the isopach map of the Horton Group in the Moncton Subbasin. This information indicates the considerable variation in thickness of the group within the subbasin. The Memramcook, Albert and Moncton formations may similarly exhibit considerable thickness variation. Thus, for example, the Memramcook Formation may vary from $140-2350 \mathrm{~m}$, the Albert Formation from $165 \mathrm{~m}$ (Gussow 1953) to a known maximum of $1800 \mathrm{~m}$ (Howie 1979) and the Moncton Formation from $100-240 m$ (see Carter and Pickerill 1985). It must be emphasized that these figures are only from available surface and subsurface data and probably represent less than maximum thicknesses.

Figure 5 represents a very schematic reconstruction of the overall spatial distribution of the varied lithofacies of the Albert Formation and has been constructed utilizing information presented herein and all previously published information on the formation. Although they exhibit complex spatial and temporal intergradation (Pick- erill and Carter 1980, three broad lithofacies dominate the depositional system. These are (i) fluvial-deltaic and associated lacustrine lithofacies which comprise major portions of the Albert Formation in both the southwest and southeast part of the subbasin, and referred to by Pickerill and Carter (1980) and Pickerill et al. (1985) respectively as the Norton and Stoney Creek deltas; (ii) alluvial fan-piedmont lithofacies which characterize the southern and southeastern margin of the subbasin adjacent to the Caledonia Uplift, and (iii) marginal lacustrine-carbonate mudflat lithofacies, in part the subject of this paper, which characterize the northern margin of the subbasin. It is also notable here that the lithofacies distribution in the central part of the subbasin is virtually unknown, although it is suspected that such lithofacies are lacustrine-dominated (cf. Pickerill and Carter 1980, Carter 1985).

The lithofacies distribution indicates an asymmetric basin characterized by an active faulted margin in the south and a passive "hinge" margin in the north. As a result, the sediments overstepped the passive basin margin from south to north and, or, southwest to northeast (Greiner 1962, Howie 1979 Pickerill and Carter 1980, Pickerill et al. 1985). This accompanied the evolution of the subbasin during Albert time from an open fluvial-lacustrine (oil shale) to closed fluvial-lacustrine-mudflat (evaporitic) basin system (Carter 1985, Carter and Pickerill 1985). The lithofacies associated with the algal swamp environment described herein developed on a platformal or terraced area that was possibly partially isolated from the "hinged" northern margin of the basin (see Carter 1985, Pickerill et al. 1985).

\section{LITHOFACIES}

\section{l. Algal swamp lithofacies}

Description: Kerogenous mudstone and carbonate with minor $(<10 \%)$ massive, non-bioturbated mudstone and fine-grained delicately laminated siltstone constitute the major lithologies. Siltstones are up to $15 \mathrm{~cm}$ in thickness, exhibit sharp non-erosive bases and sharp tops and are commonly normally graded. Kerogenous mudstones are dark grey to dull black, organic-rich and pyritiferous (Fig. 6). In thin section, the organic material is typically amorphous red, red-brown to yellowish-brown but also is 
composed of minor proportions of poorly preserved plant material (possibly chlorophyte - see Fig. 6b). Associated detrital material includes quartz, feldspar, muscovite, sericite and unidentified clays. Carbonate assumes two forms:

(i) Light grey, aphanitic, internally structureless nodular carbonate composed of variably and irregularly shaped and sized (up to several centimetres in diameter) nodules (Fig. 6a). Individual nodules are randomly oriented with respect to stratifaction, others show crude elongation and alignment of long axes parallel to stratification while others coalesce into discrete horizons.

(ii) Thin and elongated algal sheaths or thalli up to $15 \mathrm{~mm}$ in length and $3 \mathrm{~mm}$ in width and enclosed in a matrix of kerogenous mudstone (Fig. 6c). Sheath density is extremely variable ranging from isolated to highly dense horizons of variable thickness $(30-60 \mathrm{~mm})$. Individual sheaths are vari- ably shaped, commonly elongated, S-shaped or spherical, with many of the latter exhibiting quartz grain cores and therefore decidedly oncolitic (Fig. 6d). Internally, most are structureless and marked by neomorphic replacement by micrite or pyrite; more rarely the sheaths or oncolites are laminated.

These two forms of carbonate are complexly inter-related; they may each occur discretely or may, alternatively, occur in association and with extremely variable proportions of one or the other.

Interpretation and Remarks: The organicrich, pyritiferous, kerogenous mudstones which show no evidence of biogenic disturbance clearly formed in anoxic or reducing conditions. The organic material was presumably formerly dominantly algal in origin (cf. King 1963), though there is no specific evidence to substantiate this. The disseminated pyrite is presumed to be authi-

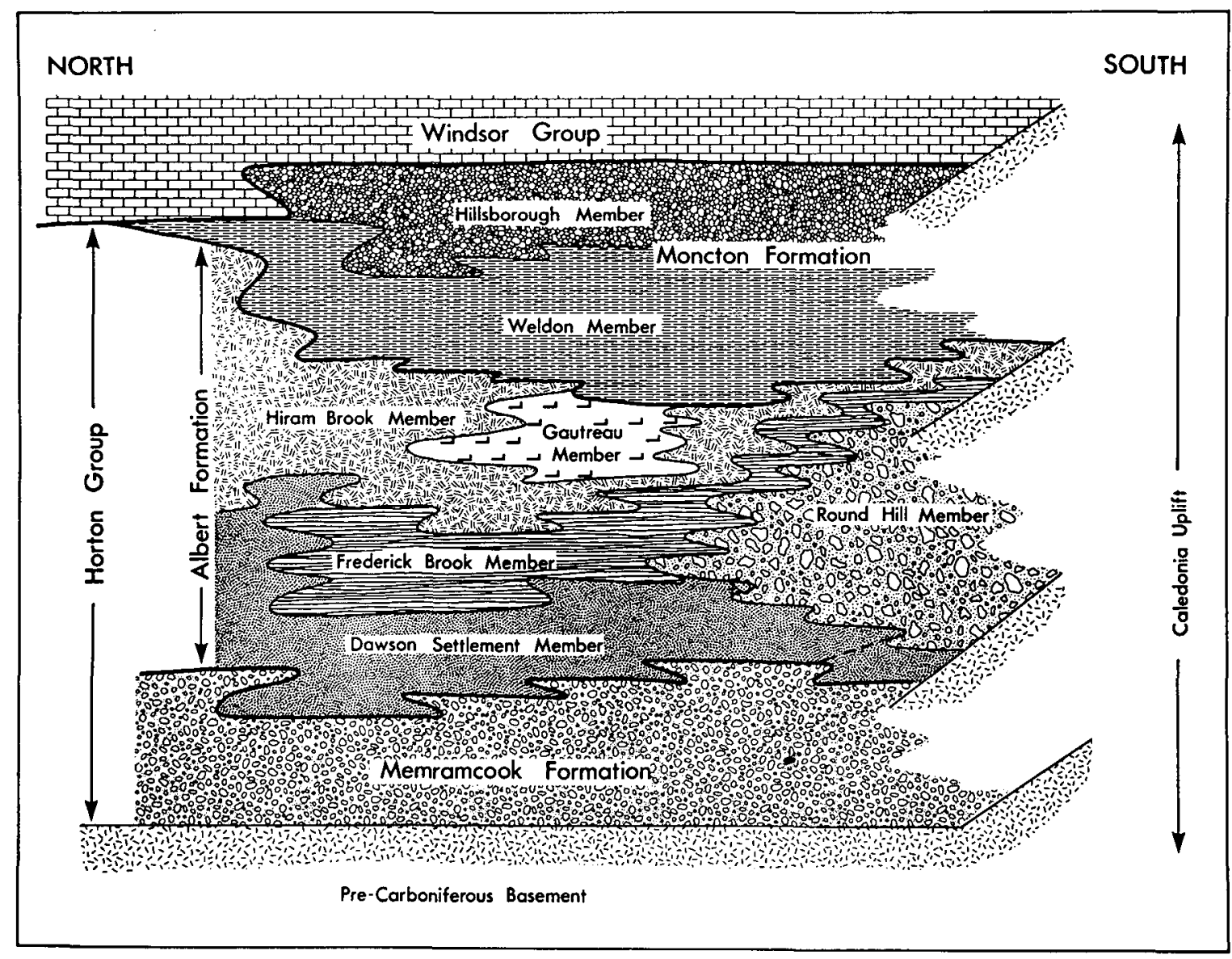

Fig. 3 - Schematic representation of group, formational and member relationships of the Horton Group in the Moncton Subbasin northwest from the Caledonia Uplift. No vertical or horizontal scale is implied and time lines are essentially horizontal (after Carter 1985, Carter and Pickerill 1985, Pickerill et al. 1985). 
ALBERT FOFMMATION STRATIGRAPHY AND FACIES RELATIONSHIPS

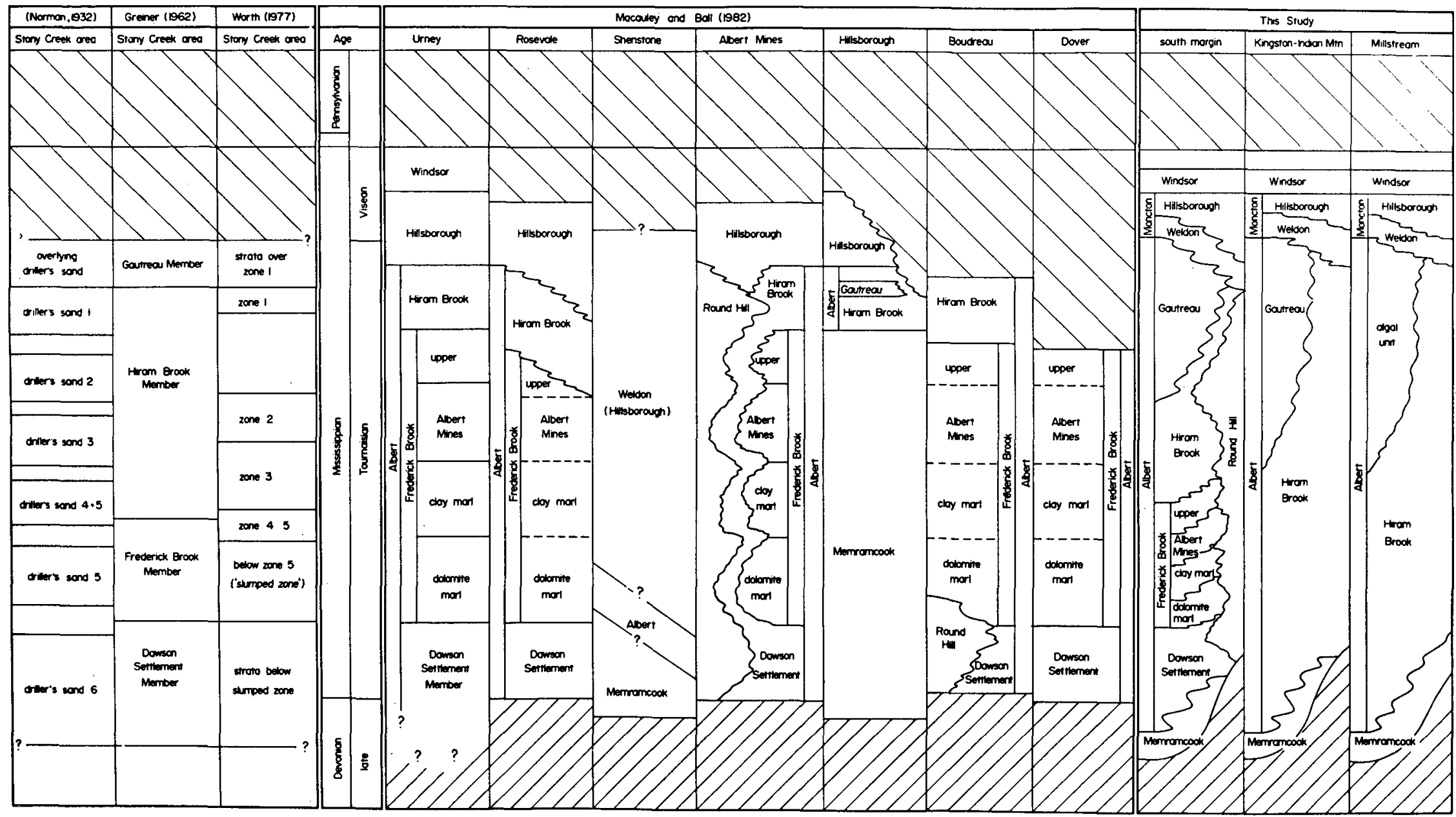

要

Fig. 4 - Compilation of varied stratigraphic terminologies of the Albert Formation of the Moncton Subbasin (after Carter 1985, Carter and Pickerill 1985). 
genic. Within this stagnant anoxic environment, inorganic precipitation of calcium carbonate at or near the sediment-water interface was promoted by the conditioning of semi-alkaline water by algal removal of $\mathrm{CO}_{2}$ from bicarbonate during photosynthesis. These inorganically precipitated nodular carbonates are similar, superficially, to typical calcretes or carbonate/sulphate nodules associated with surface crust development due to subaerial exposure. However, the absence of a developed crust, root structures and desiccation features together with the accumulation of organic material to promote carbonate precipitation suggest that subaerial exposure was not a prerequisite to nodule development. The associated algal material is primary and consists of phylloid or stromatolitic sheaths and oncolites (cf. King 1963, Pickerill 1981, Kalkreuth and Macauley 1984) as similarly described by many authors in present-day lacustrine environments rich in green and blue-green algal communities (e.g. Osborne et al. 1982, Abell et al. 1982, Scheider et al. 1983). The production of large quantities of algae would have changed $\mathrm{pH}$ and $\mathrm{CO}_{2}$ concentration so as to promote or cause direct precipitation of nodular calcium carbonate. The interplay of the production and decomposition of organic and algal material with the resultant variability in chemical environment resulted in the comcomplex and varied vertical variation of bituminous mudstones and nodular, algal or mixed nodular and algal carbonates.

These organic-rich and carbonate-rich sediments accumulated in an anoxic environment that was obviously extremely quiescent and not subject to extensive wave or current activity. By comparison with both present-day (e.g. 'Gould 1970, Coleman et al. 1970) and ancient (e.g. Wanless et al. 1970) analogues we interpret the depositional environment as a stagnant swamp (cf. Pickerill 1981). Although ancient analogues are rarely described in the literature we assume this to be a result of (i) the original geographically restricted development of such swamp environments and, perhaps as observed in present-day situations, the more typical development of interdigitate stromatolitic facies (e.g. Osborne et al. 1982) and (ii), as a corollary, their low preservation potential and increased observational bias toward such carbonate and stromatolitic facies. Interpretation as a swamp environment is made not only on the basis of detailed analysis of the lithofacies themselves but also with respect to associated lithofacies. Available data indicate that underlying strata were deposited on the delta plain of the Norton delta in a region where fluvial influence as such was not pronounced (Pickerill 1981, Pickerill et al. 1985), except in the form of the associated delicately laminated or normally graded siltstones which we interpret as being periodically introduced into the swamp by overbank flooding from major fluvial channels. It is difficult to envisage any environment on this delta plain other than a swamp in which these lithofacies accumulated (cf. Wanless et al. 1970).

It must be emphasized that the algal swamp lithofacies are not exposed on surface and, instead, have been recognized from three drill cores from the Lower Millstream area, $10 \mathrm{~km}$ west of Sussex (Fig. 2), (Gulf Minerals Canada Inc. LM8, 9 and 10). The lithofacies can also be recognized in cores obtained by Inco Minerals Limited from the same area. All of these cores are closely located geographically and therefore the areal extent of the lithofacies is difficult to assess. Stratigraphically, however, the lithofacies are at least $130 \mathrm{~m}$ thick.

\section{Marginal lacustrine lithofacies}

Two distinctive marginal lacustrine subenvironments have been recognized in the Albert Formation (Pickerill and Carter 1980, Carter 1985, Pickerill et al.1985), but as noted previously both have been inadequately described in the literature. Both exhibit evidence of ephemeral exposure in the form of desiccation cracks and rain prints but each possess a distinctive and contrasting package of lithotypes to warrant separate description. The two marginal lacustrine sub-environments are (i) carbonate mudflat and (ii) shoreface.

\section{2a. Carbonate mudflat lithofacies}

Description: Thinly interbedded dolomitic shales, siltstones, minor carbonates and rare kerogenous and sub-kerogenous mudstones characterize the lithofacies. The dolomitic shales are brittle to platy, sub-kerogenous and contain disseminated blebs and nodules of pyrite, rare gypsum and fluorite (restricted to highly contorted zones - see 


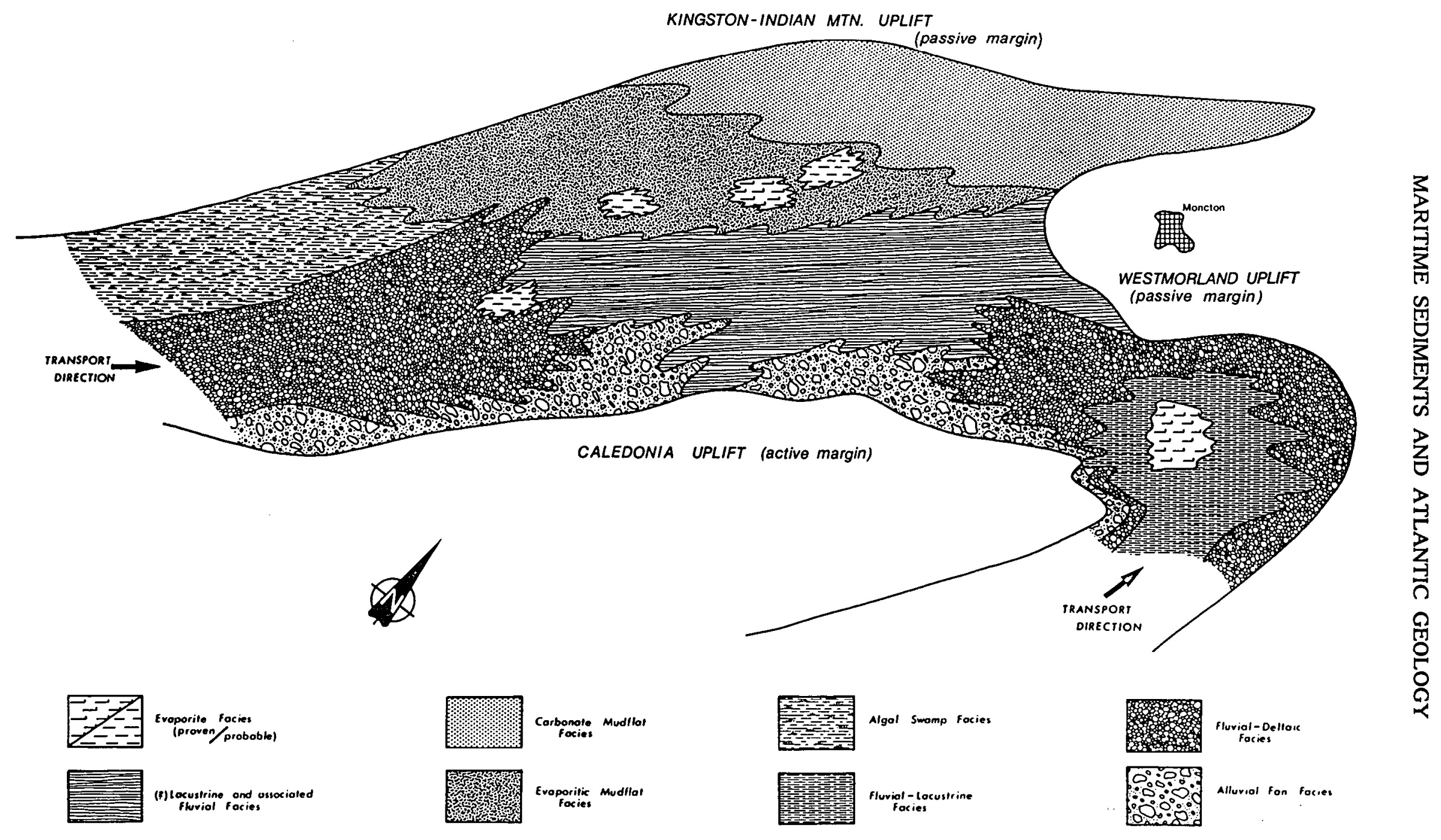

D.C. Carter $19 a 5$

Fig. 5 - Schematic distribution of lithofacies of the Albert Formation, Moncton Subbasin, southeastern New Brunswick. 
below). They comonly possess lenticular laminae of very fine-grained sandstone or siltstone which alternate with more continuous laminae of fine-grained siltstone or mudstone. They are between $5-60 \mathrm{~cm}$ thick and constitute approximately $70 \%$ of the total thickness within an individual section or outcrop. Geochemical analyses indicate the shales to be phosphatic (Pickerill and Carter 1980, Pickerill et al. 1985). Interbedded with the dolomitic shales are up to $20 \mathrm{~cm}$ thick interbeds of argillaceous limestones, dolomitic siltstones and aphanitic parallel laminated dolostones, which constitute the remaining $30 \%$ of the individual sections or outcrops and all of which exhibit minor bioturbation. Rarely, the siltstone beds exhibit normal grading. Minor carbonate "rip-up" breccias may also be present, though are certainly not diagnostic of the sub-environment, as they are equally as common in the evaporitic lacustrine litho-facies. Abundant comminuted plant and paleoniscoid debris' together with rare disarticulated crosspterygians (see Greiner 1977) are present in all lithologies. As noted above, desiccation cracks and rare rain prints are also present.

Interpretation and Remarks: Analogues of these sediments have been previously described by many authors, including Eugster and Hardie (1975), Surdam and Wolfbauer (1975) and Smoot $(1978,1983)$ from the carbonate mudflat facies of the lacustrine Green River Formation (Eocene) of Wyoming and Link and Osborne (1978) and Link (1983) from the Miocene and Pliocene mudrockcarbonate lacustrine facies of Ridge Basin, California. Similar to these examples, we interpret the lithofacies as having formed in a periodically exposed marginal lacustrine mudflat.

We regard the extensive dolomitization in this lithofacies as primary in origin resulting from precipitation of primary dolomite or recrystallization of pre-existing calcite during capilliary movement of high $\mathrm{Mg} / \mathrm{Ca}$ concentrated brines to the sedimentwater interface. Mineralogically, all the sediments are rich in quartz, dolomite, illite, albite, kaolinite and analcime (Worth 1977). The analcime possibly formed from the reaction of montmorillonite with salinealkaline waters during the dolomitization process (cf. Link and Osborne 1978).

The occurrence of phosphate is regarded as similar in origin to that reported in the periodically flooded carbonatemudflat of the Wilkins Peak Member of the Green River Formation by Mott and Drever (1983). There, phosphate deposition is inferred to have occurred by replacement of calcite during flooding due to a decrease in $\mathrm{pH}$ conditions and lower ratios of bicarbonate to phosphate in the presence of fluorine. Precipitation of phosphate ceased as a result of either a rise in $\mathrm{pH}$ caused by evaporation or a decrease in the ratio of phosphate to bicarbonate caused by the removal of phosphate by apatite. It is notable that no phosphate is present in the evaporitic lacustrine environment.

We interpret the thin graded siltstone layers as sheet flood deposits produced by periodic storms which invaded the marginal carbonate mudflats. The carbonate "rip-up" breccias are interpreted as having formed from penecontemporaneous erosion of carbonate layers during storm-related activity (cf. Link and Osborne 1978, Hardie et al. 1978, Smoot 1983). The presence of kerogenous and sub-kerogenous mudstones indicates periodic flooding of the carbonate mudflat and the temporary maintenance of a shallow standing ephemeral lake.

Marginal carbonate mudflat lithofacies are best exposed on surface in the Indian Mountain area, $10 \mathrm{~km}$ northwest of Moncton (Fig. 2), where approximately $200 \mathrm{~m}$ of typical strata are present. There, as indicated in Figure 8, the base of the Albert Formation is lithologically conformable (although structurally in part in fault contact) with the underlying Memramcook Formation (Carter and Pickerill 1985, Carter 1985, Pickerill et al. 1985). Parts of the sequence at Indian Mountain exhibit extensive ductile deformation due to soft-sediment compaction-loading and dewatering (Fig. 7) and brittle deformation due to post-compaction tectonism.

\section{2b. Marginal lacustrine (shoreface) lithofacies \\ Description: Lithologically, 0.5- $\mathrm{lm}$ thick fine- to medium-grained sandstones inter- bedded with shales or mudstones up to $0.5 \mathrm{~m}$ but typically $0.2-0.4 \mathrm{~m}$ thick are the char- acteristic lithofacies. Sandstones exhibit a wide variety and in various combinations of the following sedimentary structures: desiccation and, or, synerisis cracks, rain}



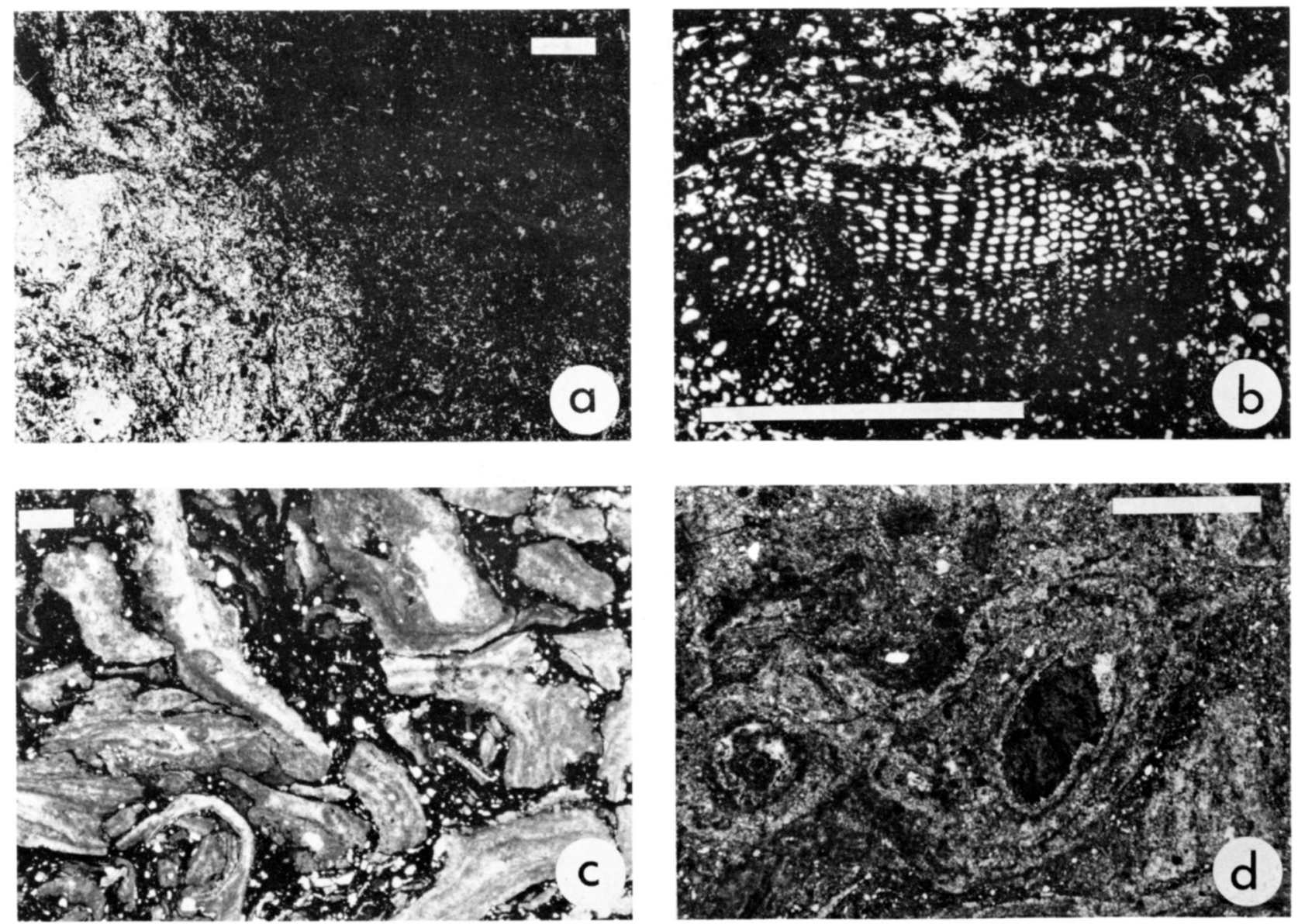

Fig. 6 - Algal swamp lithofacies, Albert Formation, Moncton Subbasin. a) Diffuse contact between diagenetic carbonate nodule (left) and kerogenous mudstone (right). b) Poorly preserved plant fragment enclosed in kerogenous mudstone rich in quartz and feldspar grains. c) Laminated algal (?) stromatolitic sheaths enclosed within a kerogenous mudstone matrix. Note the well-preserved internal lamination of the algal sheaths. d) Spherical pisolites (oncoids) formed of laminated (?)stromatolitic carbonate surrounding quartz cores and enclosed within a kerogenous mudstone matrix. All photomicrographs in transmitted light, parallel nicols. Specimen a from LM8, specimen b and c from LM9, and specimen d from LMl0 (see Carter 1985 for details). Bar scale in a, c, $d$ is $1 \mathrm{~mm}$; in b is $\mathrm{lcm}$.

prints, wave ripples, flaser beds (Fig. 9d), climbing ripples, oncolitic (pisolitic) horizons (Figs. 9a, c), convolute lamination and shallow channels. They are typically well sorted, horizontally laminated or exhibit large-scale low angle cross-stratification. Bioturbation is generally absent, though a single example of a large scale (?fish produced) burrow was observed in a $0.5 \mathrm{~m}$ thick parallel and cross-laminated sandstone (Fig. 9b). Interbedded shales or mudstones exhibit a variety of dewatering structures formed as a result of fluidization by rapid deposition of overlying sandstones. They may contain thin sandstone interbeds which exhibit desiccation cracks, rain prints, or wave ripples.
Minor lithologies include rare developments of rip-up breccias with clasts of shale and, or, mudstone with algal (?stromatolitic) coatings enclosed in a quartz-rich sandstone matrix. The aforementioned oncolite horizons may exhibit inverse to normal grading (Fig. 9a) which may be the result of transport or, alternatively, may be "rooted" due to in-situ growth.

Interpretation and Remarks: The assemblage of lithologies and their abundant and diverse sedimentary structures indicates deposition in an environment subject to at least periodic emergence. Many of the sedimentary structures are indicative of high energy conditions developed well within 

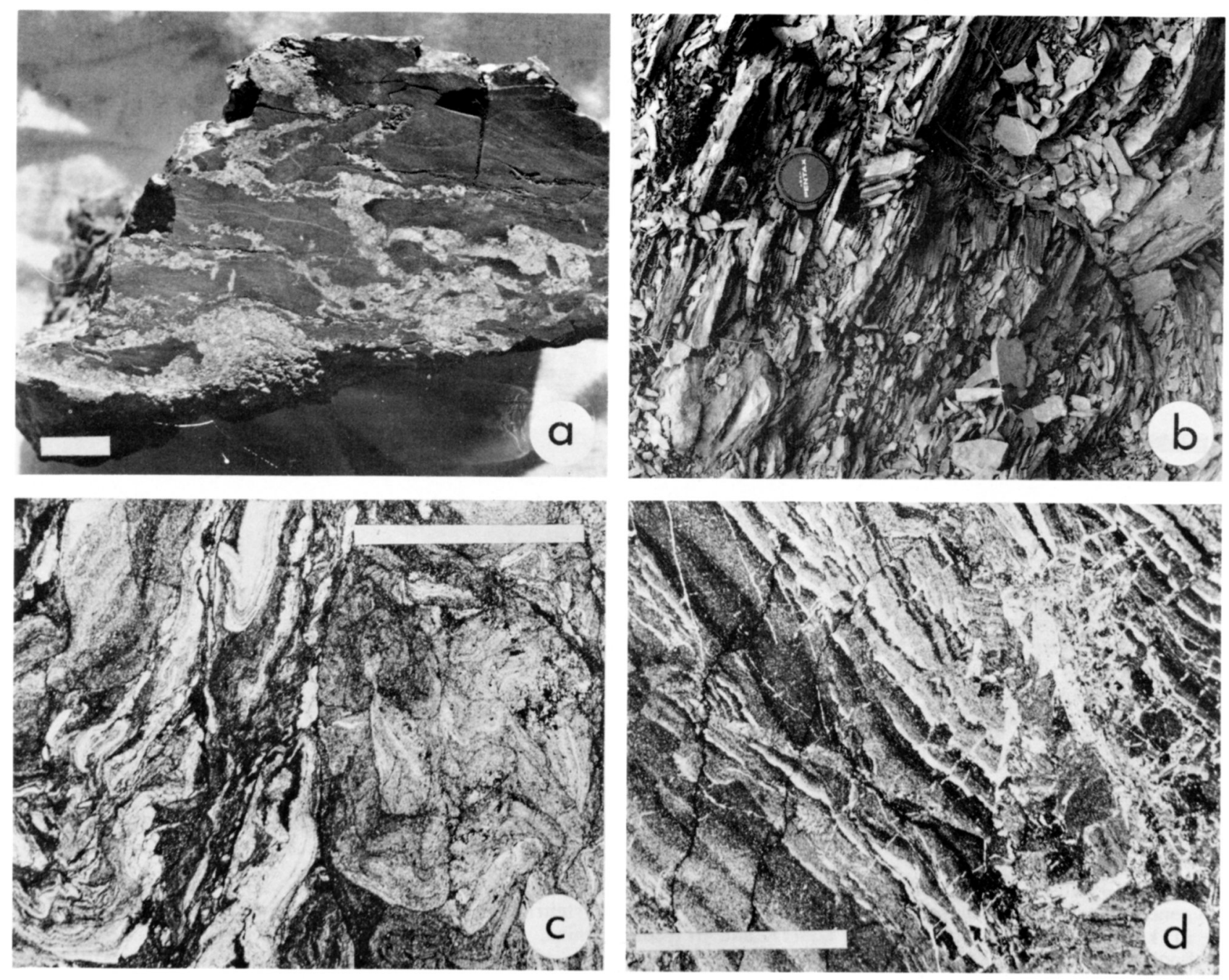

Fig. 7 - Marginal lacustrine lithofacies (carbonate mudflat), Albert Formation, Moncton Subbasin. a) Dark grey to black shale heavily veined by secondary orange brown calcite and ankerite. b) Thinly interbedded siltstone and shale, siltstones exhibiting small-scale cross-lamination and normal grading. Stratigraphic top to left. c) Highly contorted silty mudstone exhibiting syndeposition or pre-compaction deformation. d) Brecciated shale infilled by secondary calcite within both concordant and discordant veins and small-scale normal and reverse faults. All sections or samples from Indian Mountain. Bar scale in a, $c$ and $d$ is lcm; lens hood in $b$ is $50 \mathrm{~mm}$ diameter. Photomicrographs $\mathrm{c}$ and $\mathrm{d}$ in transmitted light, parallel nicols.

wave base. We therefore interpret the lithofacies as having formed in a marginal lacustrine shoreface environment. The ripup breccias and perhaps the graded oncolitic horizons probably represent stormgenerated deposits formed in such an environment. The lithofacies are not wellexposed on surface though a well-developed section can be observed at Norton (Fig. 10), $20 \mathrm{~km}$ southwest of Sussex, where their significance was first identified (Pickerill and Carter 1980, Pickerill et al. 1985). Its spatial development within the Moncton
Subbasin is, therefore, not clearly delineated though because of the restricted nature of a lacustrine shoreline facies, be it modern or ancient, it is probably not overly significant.

A similar assemblage of sedimentary facies containing a comparable suite of internal sedimentary structures has been described from Triassic marginal shoreline deposits of eastern Greenland by Clemmensen (1979) and from the Pliocene Ridge Basin of California by Link and Osborne (1978). 


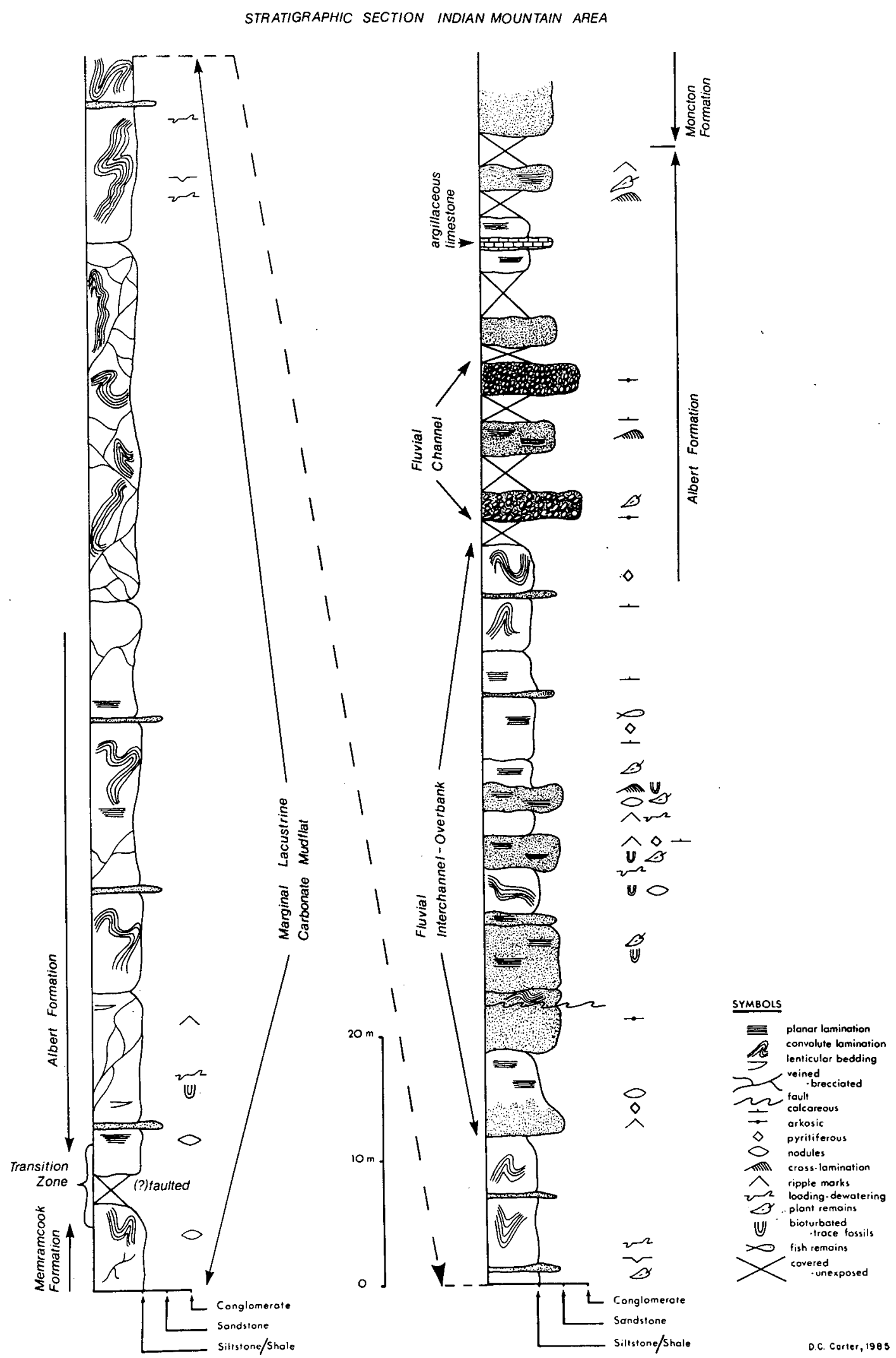

Fig. 8 - Measured stratigraphic section of the Albert Formation in the Indian Mountain area. 

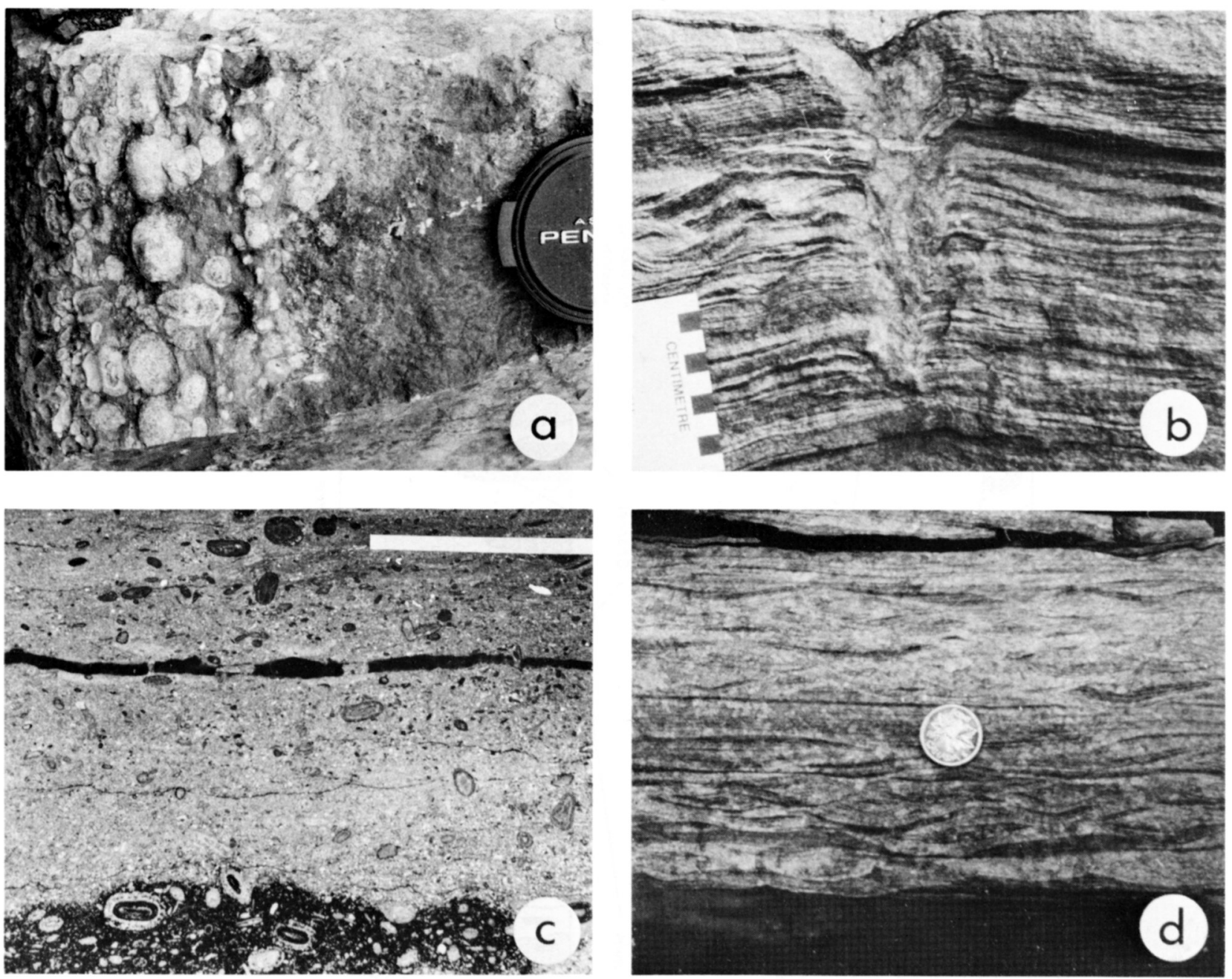

Fig. 9 - Marginal lacustrine lithofacies (shoreface), Albert Formation, Moncton Subbasin. a) Field photograph of inverse to normally graded oncoids, stratigraphic top to left, lens hood $50 \mathrm{~mm}$ in diameter. b) Parallel to low angle corss-laminated silty sandstone exhibiting a large vertical (?)fish produced burrow. c) Photomicrograph of non-rooted oncoids within a parallel laminated siltstone matrix in transmitted light, parallel nicols. Bar scale is $\mathrm{lcm}$. d) Parallel and cross-laminated, flaser bedded silty sandstone with well-developed wave formed ripples. Coin diameter $2 \mathrm{~cm}$. All figures from Norton.

\section{Shallow evaporitic lacustrine lithofacies}

Within the Albert Formation two shallow water lacustrine sub-environments have previously been recognized, the descriptor "shallow" being used in relative terms because of the absence of absolute depth indicators (Pickerill and Carter 1980, Carter 1985, Pickerill et al. 1985). These two sub-environments have been referred to by Pickerill and Carter (1980), Carter (1985), and Pickerill et al. 1985) as clastic shallow lacustrine and evaporitic shallow lacustrine. The clastic shallow lacustrine lithofacies, its depositional environment and spatial and temporal development within the Moncton Subbasin has been described in detail elsewhere (e.g. Pickerill and Carter 1980, Macauley and Ball 1982) essentially because of economic significance with respect to kerogen content and intimate association with oil shales. The evaporitic lacustrine, lithofacies, however, has been inadequately documented.

Description: Lithotypes are best known from well cuttings and core data in the Weldon-Gautreau and Cornhill areas, respectively $25 \mathrm{~km}$ southeast and $55 \mathrm{~km}$ southwest of Moncton (Fig. 2). In these areas, halite, gypsum, glauberite, anhydrite and dolostone with associated shales and siltstones con- 
stitute the lithotypes and occur in the upper part of the Albert Formation. Surface exposure as such is unknown, though we regard those exposures along the North River near Wheaton Mills and Boyd and Downing Creek near Upper Dorchester (Fig. 2) as transitional, respectively, between the carbonate mudflat and shallow lacustrine and shallow evaporitic lacustrine lithotypes (cf. Greiner 1962). At these locations, black or grey shales, sulphate-rich mudstones (Fig. $\mathrm{llb}$ ) and thin medium-grey siltstones and carbonate rip-up breccias similar to the typical carbonate mudflat lithofacies may be observed (Fig. lla). However, unlike more typical carbonate mudflat lithofacies, is the occurrence of evaporitic minerals such as gypsum, halite and ?shortite (see Figs. llc, d). Additionally, bioturbation is absent and there is no evidence of any subaerial exposure in the form of desiccation cracks or rain prints.

Interpretation and Remarks: Historically, there has been considerable debate on whether or not these salts and associated lithofacies are marine (e.g. Greiner 1962) or non-marine (e.g. Webb 1977) in origin. Pickerill and Carter (1980) noted that the occurrence of glauberite suggested a nonmarine origin. However, in the classic Zechstein 2 of Germany a thick glauberite unit occurs below the polyhalite (Braitsch 1971), an occurrence also predicted by computer modelling reported by Hardie (1984, table 7) where, based on thermodynamic calculations, glauberite can occur in the low concentration $\mathrm{CaSO}_{4}$ zone in association with calcite, gypsum, anhydrite and halite. Thus, the occurrence of glauberite is in itself not the definitive non-marine indicator it has been assumed to be in the past. However, the fact that the lithofacies pass directly into associated non-marine strata (see below) and the absence of any marine strata in the Horton Group elsewhere in eastern Canada (Carter and Pickerill 1985) together suggest a nonmarine origin. Confirmation of this, perhaps by trace element, isotope geochemistry and fluid inclusion analysis of the evaporites is yet forthcoming.

We therefore interpret this distinctive assemblage of lithotypes and its characteristic evaporitic suite as having formed in a shallow evaporitic lacustrine environment.
Ephemeral and perennial saline lakes are commonly developed within and basinward of carbonate mudflats in both recent and ancient analogues. In the northern part of Death Valley, California, for example, Hardie et al. (1978) have described comparable lithofacies (including gypsum, halite and glauberite) forming in shallow evaporitic lakes, as have Eugster and Hardie (1975) from Saline Valley California. The shallow water origin of this lithofacies is indicated by its lateral and sharply defined transition into coeval fluvial-deltaic sediments, as indicated for example by Howie (1968, fig. 7) in the Stoney Creek oilfield.

The evaporitic minerals dispersed throghout the various associated lithotypes have been previously described as "hoppers" "casts" or "molds" of or after calcite, halite or gypsum (e.g. Greiner 1974). We interpret them as crystal molds after crustal or intrasediment growth and dissolution of evaporite crystals now partially or totally filled by calcite. Similar occurrences have been reported from the Green River Formation where Eugster and Kelts (1983) suggest the molds to have initially been a $\mathrm{Na}-\mathrm{Ca}$ carbonate (gaylessite, pirssonite or shortite). Smoot (1983) has described similar aggregates of euhedral shortite crystals in dolomitic mudstones of the Wilkins Peak Member of the Green River Formation. Other analogues include those described by Maglione (1980) and Bousquet and Maurin (1980).

Thie isolated occurrences of this lithofacies suggest formation in localized topographic depressions (shallow ponds or lagoons) within the subbasin; whether or not these depresions were perennial, ephemeral (playa) or even both is not clearly understood at this time. Both perennial and ephemeral lacustrine environments produce a similar suite and range of salts and associated clastics and carbonates (Hardie et al. 1978).

As previously noted, the evaporitic lacustrine lithofacies sensu stricto are not exposed on surface, but transitional and intergradational lithofacies are exposed in the North River and Boyd-Downing Creek areas. In the North River area, kerogenous and sub-kerogenous shales are absent and the collective lithotypes, together with their evaporitic mineral associations, are indicative of deposition in close association 

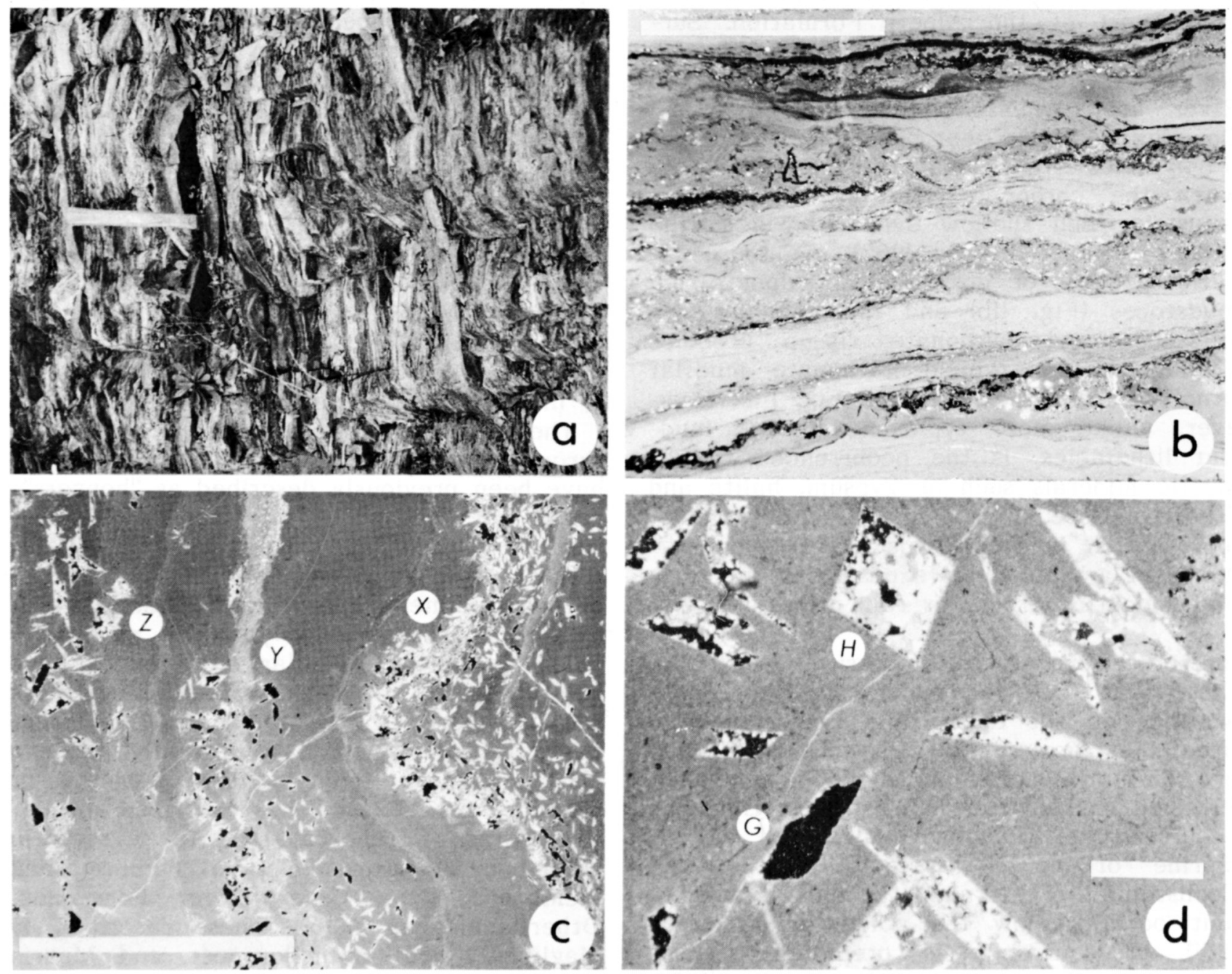

Fig. 10 - Shalow evaporitic lacustrine lithofacies, Albert Formation, Moxcton Subbasin. a) Thinly interbedded shale, silty shale and mudstone with lighter coloured storm sheet sandstones. Stratigraphic top to left and hammer for scale. b) Photomicrograph of massive to parallel laminated sulphate-rich mudstone with abundant disseminated evaporite crystal molds. c) Photomicrograph of massive evaporitic mudstone with continuous crusts $(X)$, discontinuous crusts $(Y)$ and intrasediment crystal molds (Z) completely or partially pseudomorphed by calcite. d) Photomicrograph of massive evaporite mudstone showing complete and incomplete replacement of evaporite crystal molds by sparry calcite. Mold form may represent distorted halite $(\mathrm{H})$ or lath-shaped swallow tail gypsum or shortite (G). Photomicrographs in transmitted light, parallel nicols; bar scale is $\mathrm{lcm}$ in b, c; $1 \mathrm{~mm}$ in $\mathrm{d}$; all samples from North River.

with the marginal carbonate mudflat environment. The evaporitic sediments of the Cornhill deposit therefore presumably developed in a relatively small, in terms of known areal extent, depression or pan on this carbonate mudflat. In Figure 4 the position of other possible depressions are outlined in which salt deposits may have accumulated. These have been located utilizing gravity data and it must be emphasized that no surface outcrop or drillhole data are yet available to substan- tiate the presence of thick bedded evaporites as seen at Gautreau or those proposed from the single drill hole intersection at Cornhill.

Evaporitic sediments of the Gautreau deposit, on the other hand, were deposited in association with shallow clastic lacustrine lithofacies, as revealed in surface outcrop in the Boyd-Downing Creek area. There, evaporitic mineral associations occur intimately with siltstones and kerogenous and sub-kerogenous shales. The evaporitic mud- 
Albert Fm., Stratigraphic Section, Norton Area
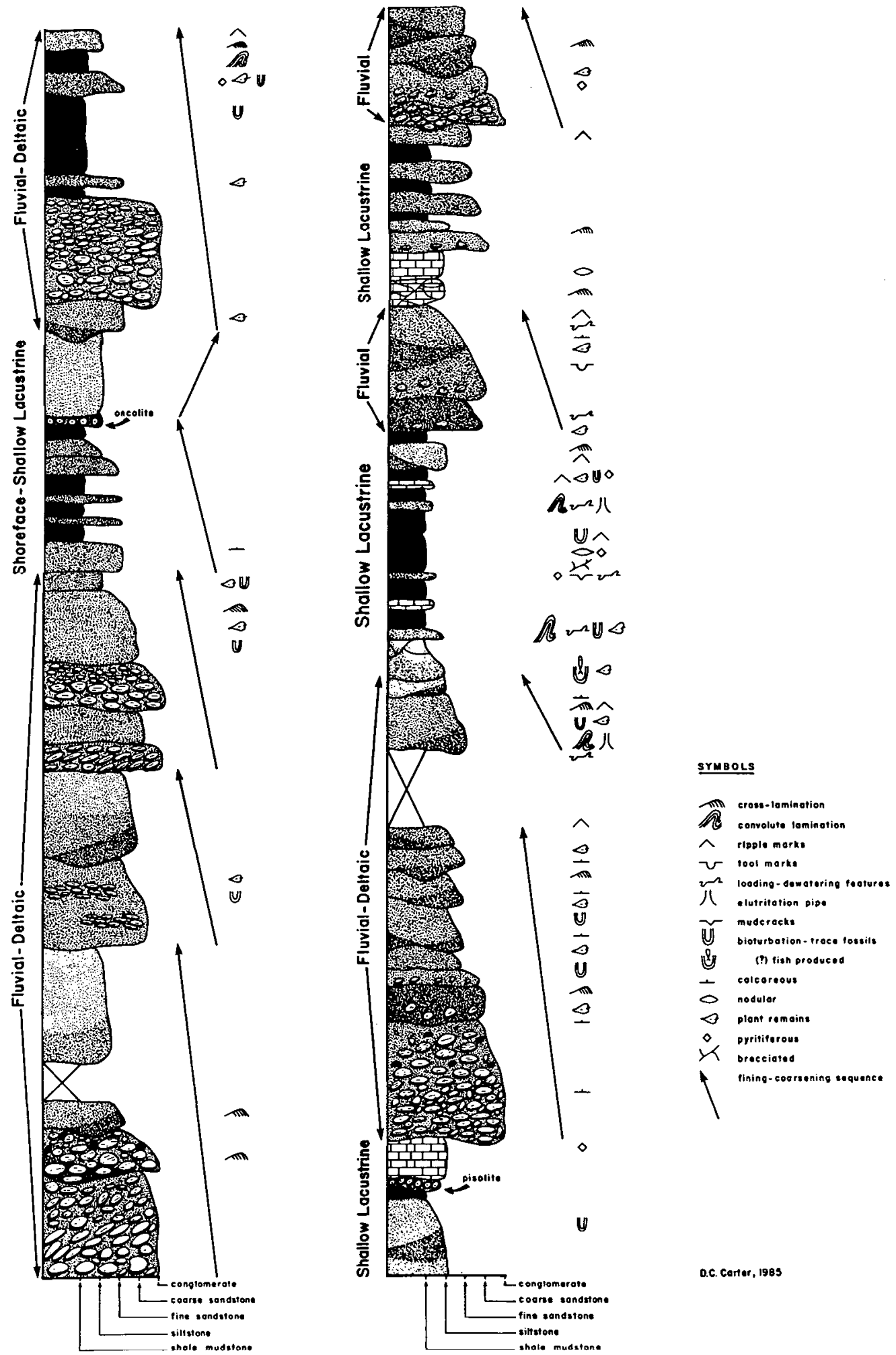

Fig. Il - Stratigraphic section and environmental interpretation of the Albert Formation at Norton, Moncton Subbasin, southern New Brunswick. Vertical scale is $\mathrm{lcm}=$ ca.5m (after Carter 1985). 
flat on which these evaporites developed was obviously more restricted, this probably being related to proximity to the tectonically and sedimentologically active basement of the Caledonia Uplift and to the coeval and areally extensive development of fluvial-deltaic lithofacies characteristic of the Stoney Creek delta.

\section{SUMMARY AND CONCLUSIONS}

In this paper we have emphasized and described but three of the depositional environments which constituted an integral part of the Albert Formation of the Moncton Subbasin. As previously noted, other depositional environments and their associated lithofacies, such as the alluvial fan, fluvial-deltaic and lacustrine environment sensu stricto have all previously been described in detail mainly as a result of their association with oil shale. Until now, the algal swamp, marginal lacustrine and shallow evaporitic lacustrine lithofacies have only briefly been noted (Pickerill et al. 1985).

With respect to the spatial distribution of these varied depositional environments, it is clear that alluvial fans and associated lithofacies occur proximal to the Caledonia Uplift, their major sediment source. These lithofacies exhibit thinning and fining relationships when traced laterally into the depositional basin (McCutcheon 1978, Pickerill and Carter 1980, Carter 1985, Pickerill et al. 1985). Fluvial-deltaic and associated lacustrine lithofacies which developed on the delta plains formed in distinctive areas, one in the southwest portion of the basin (the Norton delta) and the second in the southeastern end of the basin (the Stoney Creek delta). Sediment derivation of the former was from the southwest and the latter from the south (Howie 1979, Pickerill and Carter 1980). Typically the lithofacies are complexly inter-related both spatially and temporally amongst themselves and with alluvial fan lithofacies (see for example Macauley et al. 1984).

Algal swamp lithofacies are developed in the Lower Millstream area (Fig. 2) and are known only from closely spaced drill cores in a structurally complex area. As such their spatial distribution is unknown but it is notable that they have not been identified elsewhere in the depositional basin. The algal swamp developed on or adjacent to the Norton delta on a platformal area which was generally removed from major fluvial influence except perhaps for overbank deposition associated with flood periods. There is insufficient evidence available to warrant additional comment on the nature of this platformal area; whether or not, in fact, it was simply a basement high or a tectonically active basement block or indeed both.

Shoreface lithofacies are also poorlyexposed on surface but are known at least from the Norton area (Figs. 2, 10) where they developed as a result of lacustrine transgression across the Norton delta followed at a later date by regression of the lake. Predictably such lithofacies are developed elsewhere wherever extensive lacustrine facies are present but their spatial and temporal distribution awaits future analysis. Carbonate mudflat lithofacies are exposed in the Indian Mountain area (Fig. 2), where they overlie similar lithofacies of the Memramcook Formation and are in turn overlain by fluvial strata more typical of the overlying Moncton Formation (Fig. 8). This succession therefore reflects a change from deposition in a closed basin system opening up into a more open fluvial-dominated system.

Shallow evaporitic lacustrine lithofacies sensu stricto are known from drill cores in both the Cornhill and Weldon-Gautreau areas and predicted occurrences are indicated in Figure 5. On surface the lithofacies are known from the North River area which we regard as closely associated with the carbonate mudflat depositional environment and from the Boyd-Downing Creek area where they formed in close association with shallow clastic lacustrine environments.

\section{ACKNOWLEDGMENTS}

Support for this work was provided partially by the New Brunswick Department of Natural Resources and more fully by the Natural Sciences and Engineering Research Council of Canada Grant A3857 to R.K. Pickerill, both of which are gratefully acknowledged. For their comprehensive reviews of the initial version of the manuscript we are grateful to Clint St. Peter and Steve McCutcheon. We also thank L. Fyffe, W. van de Poll and J.P. Anderle for active discussion on the Albert Forma- 
tion. The manuscript was prepared by Sherri Townsend and technical assistance provided by $\mathrm{P}$. Chenard and R. McCulloch.

ABELL, P.I., AWRAMIK, S.M., OSBORNE, R.H. and TOMELLINI, S. 1982. Plio-Pleistocene lacustrine stromatolites from Lake Turkana, Kenya: morpho$\operatorname{logy}$, stratigraphy and stable isotopes. Sedimentary Geology, 32, pp. 1-26.

BELT, E.S. 1968. Post-Acadian rifts and related facies, eastern Canada. In Studies of Appalachian Geology: Northern and Maritime. Edited by E.-An Zen, W.S. White, J.B. Hadley and J.S. Thompson, Jr., Wiley Interscience, New York, pp. 95-II3.

BOUSQUET, P. and MAURIN, A.F. 1980. Evaporitic habitats of the Michigan Silurian (U.S.A.). In Evaporite Deposits: illustration and interpretations of some environmental sequences. Graham and Trotham Ltd., London, p. 59; plates on pp. 230233.

BRAITSCH, O. 1971. Salt Deposits - their origin and composition. Springer-Verlag, Berlin, 297p.

CARTER, D.C. 1985. The Late Devonian-Early Carboniferous Albert Formation: A sedimentological approach to depositional history and facies relationships in a fluvial/deltaic and lacustrine basin. Unpublished M.Sc. thesis, University of New Brunswick, 289p.

CARTER, D.C. and PICKERILL, R.K. 1985. Lithostratigraphy of the Late Devonian-Early Carboniferous Horton Group of the Moncton Subbasin, southern New Brunswick. Maritime Sediments and Atlantic Geology, 21 (in press).

CLEMMENSEN, L.B. 1979. Triassic lacustrine redbeds and palaeoclimate: The "Buntsandstein" of Heligoland and the Malmros Klint Member of East Greenland. Geologische Rundschau, 68, pp. 748-774.

COLEMAN, J.M., SHERWOOD, M.G. and SMITH, W.G. 1970. Sedimentation in a Malaysian high tide tropical delta. In Deltaic Sedimentation Modern and Ancient. Edited by J.P. Morgan. Society of Economic Paleontologists and Mineralogists, Special Publication, 15, pp. 185-197.

EUGSTER, H.P. and HARDIE, L.A. 1975. Sedimentation in an ancient playa-lake complex: the Wilkins Peak Member of the Green River Formation of Wyoming. Bulletin of Geological Society of America, 86, pp. 319-334.

EUGSTER, H.P. and KELTS, K. 1983. Lacustrine Chemical Sediments. In Chemical Sediments and Geomorphology. Edited by A.S. Goudie and K. Pye. Academic Press, pp. 321-368.

GOULD, H.R. 1970. The Mississippi Delta Complex. In Deltaic Sedimentation Modern and Ancient. Edited by J.P. Morgan. Society of Economic Paleontologists and Mineralogists. Special Publication, 15, pp. 3-30.

GREINER, H.R. 1962. Facies and sedimentary environments of Albert shale, New Brunswick. American Association of Petroleum Geologists Bulletin, 46, pp. 219-234.

GREINER, H.R. 1974. The Albert Formation of New Brunswick: a Paleozoic lacustrine model. Geologische Rundschau, 63, pp. 1102-1113.

GREINER, H.R. 1977. Crossopterygian fauna from the Albert Formation, New Brunswick, Canada and its stratigraphic - paleoecologic significance. Journal of Paleontology, 5l, pp. 44-56.

GUSSOW, W.C. 1953. Carboniferous Stratigraphy and Structural Geology of New Brunswick, Canada. American Association of Petroleum Geologists Bulletin, 37, pp. 1713-1816.

HACQUEBARD, P.A.. 1972. The Carboniferous of Eastern Canada. In 7th Congrès International de Stratigraphie et de Géologie du Carbonifère, Krefeld. Comptes Rendus, 1, pp. 69-90.

HARDIE, L.A. 1984. Evaporites: Marine or Nonmarine. American Journal of Science, 284, pp. 193-240.

HARDIE, L.A., SMOOT, J.P. and EUGSTER, H.P. 1978. Saline Lakes and their deposits: a sedimentological approach. In Modern and Ancient Lake Sediments. Edited by A. Matter and M.E. Tucker. International Association of Sedimentologists, 2, pp. 7-4l.

HENDERSON, J.A.L. 1940. The development of oil and gas in New Brunswick. Canadian Institute of Mining and Metallurgy, Transactions, 43, pp. 159178.

HOWIE, R.D. 1968. Stony Creek gas and oil field, New Brunswick. American Association of Petroleum Geologists, Memoir 9, 2, pp. 1819-1832.

HOWIE, R.D. 1979. Carboniferous evaporites in Atlantic Canada. Abstract, 9th International Congress on Carboniferous Stratigraphy and Geology, University of Illinois, Urbana, Ill., pp. 93-94.

KALKREUTH, W. and MACAULEY, G. 1984. Organic petrology of selected oil shale samples from the Lower Carboniferous Albert Formation, New Brunswick, Canada. Bulletin of Canadian Petroleum Geology, 32, pp. 38-51.

KING, L.H. 1963. Origin of the Albert Mines Oil Shale (New Brunswick) and its associated albertite. Mines Branch Research Report Rll5, Department of Mines and Technical Survey, Ottawa, 24p.

KNIGHT, I. 1983. Geology of the Carboniferous Bay St. George, Subbasin, western Newfoundland. Newfoundland Department of Mines and Energy, Memoir, l, 358p.

LINK, M.H. 1983. Fluvial facies of the Miocene Ridge Route Formation, Ridge Basin, California. Sedimentary Geology, 38, pp. 263-285.

LINK, M.H. and OSBORNE, R.H. 1978. Lacustrine facies in the Pliocene Ridge Basin Group: Ridge Basin, California. In Modern and Ancient Lake Sediments. Edited by A. Matter and M.E. Tucker. International Association of Sedimentologists, Special Publication, 2, pp. 169-187.

MACAULEY, G. and BALL, F.D. 1982. Oil shales of the Albert Formation, New Brunswick. New Brunswick Department of Natural Resources, Mineral Development Branch, Open File Report 82-12, 173p

MACAULEY, G., BALL, F.D. and POWELL, T.G. 1984. A review of the Carboniferous Albert Formation oil shales, New Brunswick. Bulletin of Canadian Petroleum Geology, 32, pp. 27-37.

MAGLIONE, G. 1980. An example of recent continental evaporitic sedimentation: the Chadian Basin (Africa). In Evaporite Deposits: illustration and interpretation of some environmental sequences. Graham and Trotman Ltd., London, pp. 5-9; plates pp. 74-91. 
MCCUTCHEON, S.R. 1978. Geology of the ApohaquiMarkhamville Area, Map Area R-25 (2lH/llW, $2 \mathrm{lH} / 12 \mathrm{E})$. Department of Natural Resources, Mineral Resources Branch, Sussex, New Brunswick, Map Report 78-5, 41 p.

McCUTCHEON, S.R. 1981. Stratigraphy and paleogeography of the Windsor Group in Southern New Brunswick. New Brunswick Department of Natural Resources, Mineral Resources Division, Open File Report, 81-31, 210p.

MOTT, L.V. and DREVER, J.I. 1983. Origin of Uraniferous Phosphatic Beds in Wilkins Peak Member of the Green River Formation, Wyoming. American Assocition of Petroleum Geologists Bulletin, 67, pp. 70-82.

NORMAN, G.W.H. 1932. Stratigraphy of the Stoney Creek oil and gas field, New Brunswick. Geological Survey of Canada, Economic Geology Series, 9, pp. 167-173.

OSBORNE, R.H., LICARI, G.R. and LINK, M.H. 1982 Modern lacustrine stromatolites, Walker Lake, Nevada. Sedimentary Geology, 32, pp. 39-61.

PICKERILL, R.K. 1981. Paleoenvironmental interpretation of Gulf Minerals Canada Ltd. diamond drill holes, Millstream LM8, 9, 10. Unpublished report for Gulf Minerals Canada Ltd., 33p.

PICKERILL, R.K. and CARTER, D.C. 1980. Sedimentary facies and depositional history of the Albert Formation. New Brunswick Department of Natural Resources, Open File Report, 80-3, 132p.

PICKERILL, R.K., CARTER, D.C. and ST. PETER, C. 1985. The Albert Formation - oil shales, lakes, fans and deltas. Geological Association of Canada/ Mineralogical Association of Canada Field Guide $\# 6,71 p$.

POLL, H.W. van de 1972. Stratigraphy and economic geology of Carboniferous basins in the Maritime Provinces. International Geological Congress, 24th, Montreal, 1972. Guidebook AGO, 96p.

SCHENK, P.E. 1967. The significance of algal stromatolites to paleoenvironmental and chronostratigraphic interpretations of the Windsorian Stage (Mississippian), Maritime Provinces. Geological Association of Canada, Special Paper, 4, pp. 229243.
SCHNEIDER, J., SCHRODER, H.G. and LE CAMPION-ALSUMARD, T. 1983. Algal micro-reefs: Coated grains from freshwater environments. In Coated Grains. Edited by T.M. Peryt. SpringerVerlag, New York, pp. 264-298.

SMITH, W.D. 1985. Composition and Depositional Environment of the Albert Formation Oil Shales, New Brunswick. Unpublished M.Sc. Thesis, Dalhousie University, 286p.

SMOOT, J.P. 1978. Origin of the carbonate sediments in the Wilkins Peak Member of the lacustrine Green River Formation (Eocene), Wyoming, U.S.A. In Modern and Ancient Lake Sediments. Edited by A. Matter and M.E. Tucker. International Association of Sedimentologists, Special Publication, 2, pp. 109-127.

SMOOT, J.P. 1983. Depositional subenvironments in an arid closed basin: the Wilkins Peak Member of the Green River Formation (Eocene), Wyoming, U.S.A. Sedimentology, 30, pp. 801-827.

ST. PETER, C. 1982. Geology of the Albert Formation, New Brunswick, Canada. 1982 Eastern Oil Shale Symposium, Kentucky Department of Energy and University of Kentucky, Lexington, Kentucky, pp. 39-47.

SURDAM, R.C. and WOLFBAUER, C.A. 1975. Green River Formation, Wyoming, a playa-lake complex. Bulletin of the Geological Society of American, 86, pp. 335-345.

WANLESS, H.R. BAROFFIO, J.R., GAMBLE, J.C., HORNE, J.C., ORLOPP, D.R., ROCHA-COMPOS, A., SOUTER, J.E., TRESCOTT, P.C., VAIL, R.S. and WRIGHT, C.R. 1970. Late Paleozoic deltas in the central and eastern United States. In Deltaic Sedimentation Modern and Ancient. Edited by J.P. Morgan. Society of Economic Paleontologists and Mineralogists, Special Publication, 15, pp. 215-245.

WEBB, T.C. 1977. Geology of New Brunswick Glauberite Deposits. Department of Natural Resources, Mineral Resources Branch, Fredericton, Open File Report, 77-15, 29p.

WORTH, J. 1977. Oil shale and lithofacies, Albert Formation Hillsborough sub-basin, New Brunswick. Fundy Geoservices Ltd., Report for Canadian Occidental Petroleum Ltd., 79p.

REVIEWERS: C. St. Peter S.R. McCutcheon 